\title{
Physicochemical Analysis of Sumbul-al -Teeb (Nardostachys jatamansi D.C.) Rhizome along with its HPLC Profile
}

\author{
Mohammad Rashid, Aziz ur Rahman*, Qazi Zaid Ahmad, Tajuddin, Syed Shariq Mian
}

\section{Mohammad Rashid Aziz ur Rahman*, Qazi Záid Ahmad, Tajuddin, Syed Shariq Mian \\ Department of Saidla (Unani Pharmacy), Faculty of Unani Medicine, Aligarh Muslim University, Aligarh, INDIA. \\ Correspondence}

\section{Aziz ur Rahman}

Department of Saidla (Unani Pharmacy), Faculty of Unani Medicine, Aligarh Muslim University, Aligarh-202001, INDIA.

Phone No: +919997968933

E mail Id: rahman.mdi@gmail.com

History

- Submission Date: 27-11-2017

- Review completed: 31-12-2017;

- Accepted Date: 18-01-2018

DOI : 10.5530/pj.2018.2.49

Article Available online

http://www.phcogj.com/v10/i2

Copyright

(C) 2018 Phcog.Net. This is an openaccess article distributed under the terms of the Creative Commons Attribution 4.0 International license.

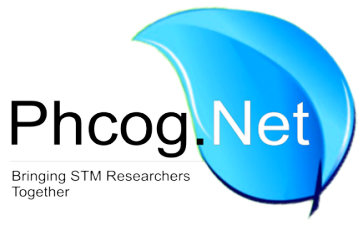

\begin{abstract}
Introduction: Sumbul-al-Teeb (Nardostachys jatamansI) is a well known traditional medicinal plant used for therapeutic effect in Unani and Ayurvedic System of Medicine. It has been reported to have many therapeutic activities like antifungal, antimicrobial, antioxidant, hepatoprotective and cardioprotective properties. It is also useful in the management of insomnia and CNS disorders. The present study aims towards the evaluation of the parameters involved in the determination of the quality and purity of Nardostachys jatamansi rhizome and its standardization. Methods: Organoleptic characters, extractive values, ash values, phyto-chemical analysis, TLC, fluorescence analysis and HPLC profile etc. were the parameters used for the standardisation of the test drug. Result: Total ash values, water and alcohol soluble extractive values, moisture contents and volatile oil percentage was found to be $7.08 \%, 3.54 \%, 2.5 \%$, $8.6 \%$ and $02 \%$ respectively. TLC profile of $N$. jatamansi shows 04,08 and 10 spots in UV short and long wavelength and exposure to iodine vapours respectively. The HPLC pattern shows 34 peaks and the peak no. 01 and 08 are major peaks having area concentration and retention time as $25.974 \%$ at $2.8 \mathrm{~min}$. and $29.967 \%$ at $4.399 \mathrm{~min}$. respectively. Conclusion: The study will provide referential information for the good quality, purity and identification for the future batches of Nardostachys jatamansi.

Key words: Phyto-chemical analysis, Quality, Standardization, Unani.
\end{abstract}

Nowadays the Indian herbal industry is flourishing at an admirable pace with remarkable increase in the introduction of new herbal pharmaceutical and cosmetic products in the market. But due to ignorance and awful supply chain management of herbal medicines, quality and purity of herbs and their products is not assured. As the efficacy and safety of herbal products is strongly based on their good quality therefore, determination of identity, quality and purity of the herbal medicines is unavoidable. The traditional approach towards standardization for obtaining good quality herbal medicines seems to be insufficient for the current herbal market which invites the need for more advanced techniques. Standardization of the crude drugs involves passport data of the drugs viz., botanical identification, and macroscopic, microscopic and molecular examination, identification of Phytochemical constituent by various chromatographic techniques and biological activity of the whole plant. ${ }^{1}$ Due to the high commerce, traders have imperilled plants and their products to adulteration and substitution.

As the rhizome of $N$. jatamansi is often contaminated and adulterated with different plant materials such as Selinium vaginatu. ${ }^{2}$ Therefore, in this study Nardostachys jatamansi DC, family - Caprifoliaceae (Valirenaceae) was selected and standardized on their physico-chemical

\section{INTRODUCTION}

characteristics along with HPLC profile. Nardostachys jatamansi is native to the Himalayan regions of India and commonly known as muskroot. ${ }^{3}$ It is an excellent remedy popular to the Indian medicinal system and is used from centuries for its health skin diseases. Medicinally it possesses anti-inflammatory, sedative/anodyne, detergent, sialagogue, desiccant, carminative, cardiac tonic, brain tonic, diuretic properties and can be used in cephalalgia, flatulence, ascites, jaundice, hepatitis, ureteralgia, cystitis etc. ${ }^{4}$ The rhizome is the source of spikenard oil. ${ }^{5}$ It has been reported that Spikenard oil contained p-maaline (18\%) and calarene (65\%). ${ }^{6}$ Monoterpenes are $\alpha$-pinene, $\beta$-pinene, $\Delta^{3}$-carene; alcohols$\beta$-eudesmol, elemol, oroselol; a semisolid long chain hydrocarbon with molecular formula $\mathrm{C}_{30} \mathrm{H}_{62}$ $\beta$-sitosterol; a terpenic coumarin - jatamansin, a polyoxygenated compound-angelicin and jamansinol have been identified by GLC. ${ }^{7,8}$ Nardostachnol 9-hydro aristolene, 1(10)-dehydroaristolene, $2 \beta$-maaline and $1,2,9,10$-tetrahydro aristolene have been isolated from roots. ${ }^{9}$ There are number of compounds reported, which have been isolated from its roots and rhizomes, e.g. sesquiterpene ketone -jatamansone..$^{10}$ Liquid alcohols - nardol, calarenol and $n$-hexacosanol; a ketonevaleranone and diethenoid benefits; it can also be used for treatment and other

Cite this article: Rashid M, Rahman A, Ahmad OZ, Tajuddin, Mian SS. Physicochemical Analysis of Sumbul-al -Teeb (Nardostachys jatamansi D.C.) Rhizome along with its HPLC Profile. Pharmacog J. 2018;10(2):278-84. 
ketone - nardostachone, $n$-hexacosen, $n$-hexacosanylisovalerate, $n$-hexacosanylarachiedate, isovaleric acid,valeranal and $\beta$-sitosterol have been reported from powdered roots. ${ }^{11}$

Other sesquiterpenes include nardostachone, jatamansinol, jatamansic acid, jatamansinone, nardostachyin, nardosinone, jatamol A and B etc. A new sesquiterpene acid and new pyranocoumarin: 2', 2'-dimethyl3'-methoxy-3', 4'-dihydropyranocoumarin were reported. Actinidine, an alkaloid was also reported. ${ }^{5}$

The present study was carried out in order to standardise the rhizome of Nardostachys jatamansi with a view to develop its quality parameters, and also to deliver referential information for the identification of the crude drug so as to check the substitution and adulteration and to ensure the effectiveness of a drug in treating different body ailments. ${ }^{12}$ Parameters include macroscopy, powder analysis, physicochemical parameters and preliminary phyto-chemical screening alongwith HPLC profile.

\section{MATERIAL METHOD}

\section{Collection of sample}

Dried rhizome of $N$. jatamansi was procured from local market of Aligarh and was properly recognized from the accessible literature and authenticated by Prof. S. H. Afaq. The sample with specimen voucher no. SAMU/NJ-R-0001/17 was deposited in the Department of Saidla, Faculty of Unani medicine, Aligarh Muslim University, Aligarh, for future reference. It was crushed and sieved to coarse powder mechanically and stored in air tight container for study.

\section{Macroscopy and organoleptic characters}

The organoleptic characters of the crude drug were observed with sensory organs and was analysed for its colour, odour and taste, size, shape, fracture and surface.

\section{Physicochemical parameters}

Ash values, alcohol and water soluble extractive values, volatile oil estimation and loss on drying of the test drug was determined as per the methods recommended by Ayurvedic Pharmacopeia of India (API).$^{13}$ and British Pharmacopeia. ${ }^{14}$

The fluorescence analysis of the rhizome powder was done by treating with the different chemical reagents and observed under Ultra violet light and day light. ${ }^{15,16}$

\section{TLC}

Thin layer chromatographic analysis of the methanolic extract of Nardostachys jatamansi was carried out via chloroform: methanol (24:1) as mobile phase in percolated silica gel $60 \mathrm{~F}_{254}$ TLC plates. Spotted TLC plates were exposed to iodine vapours in iodine chamber and were also visualized in day light and UV short and long wavelength. The Rf value of spots was determined by the given formulae..$^{14,17}$

$$
\text { Rf value } \mathrm{T} \frac{\text { Distance travelled by the Spot }}{\text { Distance travelled by the solvent }}
$$

\section{Preliminary phyto-chemical screening}

The extracts were introduced to preliminary phyto-chemical analysis and investigated for the presence of various phyto-constituents like alkaloids, carbohydrates, glycosides, flavonoids, proteins, steroids, saponins, etc. with following parameters..$^{18,19}$

\section{HPLC profile of N. Jatamansi}

HPLC profile of the methanolic extract of the N Jatamansi was done. For this Shimadzu Prominence Isocratic HPLC System equipped with LC-20 AD Solvent delivery unit, Rheodyne Injector, SPD-20A prominence Uv-vis detector system along with C18G120A column, 250x4.6 mm $5 \mathrm{U}$ with guard column was used. The methanolic extract of coarsely powdered drug was obtained with the help of soxhlet's extraction method, extract was filtered and allowed to evaporate on water bath. This dried alcoholic extract was dissolved in HPLC grade methanol and used for study. The chromatographic analyses were carried out at room temperature using reversed phase and software driven peaks were obtained (Figure 2). The pressure and flow rate was $127 \mathrm{kgf}$ and $1.0 \mathrm{ml} / \mathrm{min}$, respectively. Detector for HPLC was UV and the wavelength was 254 $\mathrm{nm}$. Mobile phase for HPLC profile of extract consisted of HPLC grade methanol (Merk life science Pvt. Ltd.) only.

\section{RESULTS AND DISCUSSION}

Modern system of medicine relies on sound experimental data, toxicity studies and human clinical studies. But there is a lack of pharmacopoeial standards on raw material / finished products. The insufficient quality standards have led to the occurrence of mild to serious adverse effects. Hence, the standardization of herbal ingredients is the basic requirement in order to establish the identity, purity and quality. ${ }^{20}$ Herbals are traditionally considered safe and are remarkably consumed by people without prescription. However, it is advocated that some can cause health problems, some are not effective and some may interact with other medicines. Standardization is crucial for the assessment of the quality, purity and authenticity of the drugs, based on the physicochemical parameters, TLC, HPLC and on the presence of active principles. ${ }^{21} \mathrm{~A}$ standardized and good quality drug is the assurance of its therapeutic effectiveness and global acceptance. Nardostachys jatamansi is a well-known drug of Unani System of Medicine used to treat various body ailments such as inflammatory conditions. Therefore, for this study Nardostachys jatamansi was selected and standardized on their physicochemical parameters such as organoleptic characters, ash values, extractive values, volatile oil estimation, fluorescence analysis, qualitative estimation, TLC along with HPLC profile.

\section{Organoleptic characters of $\mathbf{N}$. jatamansi}

Organoleptic properties are the critical parameter for the rapid identification and consumer acceptance. Sensory evaluation-visual macroscopy, colour, odour, taste, fracture are the common features helped in identification of the crude drug. The organoleptic properties of rhizome of $N$. jatamansi have been mentioned in Table 1.

\section{Physicochemical analysis of $N$. jatamansi}

Ash values, alcohol and water soluble extractive values, loss of weight in powdered drug after drying at $105^{\circ} \mathrm{C}$ and moisture contents are the indicators of the purity, quality and authenticity of any crude drug. Therefore, to standardise a herbal drug these parameters have basic importance and unavoidable. Total ash values, acid insoluble and water soluble ash values reveals the information related to the adulteration of crude drug with inorganic matter. The water and alcohol soluble extractive values indicate the amount of the extract that the drug yields in a solvent. ${ }^{16}$ Less or more extractive value indicates addition of exhausted material, adulteration or incorrect processing during drying, or storage of plant products. ${ }^{22}$ Low or high moisture contents may affect the quality of the drug and hence, its efficacy. The excessive moisture is an ideal medium for the growth of the different types of microorganisms which subsequently damages the drug. ${ }^{23}$ This drug is also well known for its oil contents. The inappropriate method of extraction of oil or distillation 
Table 1: Organoleptic characters of $\mathbf{N}$. jatamansi

\begin{tabular}{cc}
\hline Rhizome of $\mathbf{N}$. jatamansi & Characters \\
\hline Shape & Elongated and cylindrical \\
Size & Rhizomes are 2.5 to $7.5 \mathrm{~cm}$ in length \\
Colour & Dark grey rhizomes are crowned with reddish brown tufted fibers. Internally they are reddish brown in colour \\
Fracture & Easy and splintery \\
Surface & Hairy \\
Odour & Highly agreeable, aromatic \\
Taste & Acrid, slightly bitter and aromatic \\
\hline
\end{tabular}

Table 2: Physicochemical values of $\boldsymbol{N}$. jatamansi

\begin{tabular}{cc}
\hline Parameters & Observed Valuesin \% (Mean \pm SD) \\
\hline Total ash & $7.08 \pm 0.03$ \\
Acid insoluble ash & $3.71 \pm 0.18$ \\
Water soluble ash & $0.58 \pm 0.07$ \\
Alcohol soluble extract & $3.54 \pm 0.72$ \\
Water soluble extract & $2.5 \pm 0.06$ \\
Volatile oil & $02 \pm 0.04$ \\
Loss on drying & $9.12 \pm 0.12$ \\
Moisture content & $8.6 \pm 0.2517$ \\
\hline
\end{tabular}

Table 3: Fluorescence analysis of $\boldsymbol{N}$. jatamansi

\begin{tabular}{|c|c|c|c|}
\hline \multirow{3}{*}{ Reagents } & \multirow{3}{*}{ Visible light } & \multicolumn{2}{|c|}{ UV light } \\
\hline & & Short & Long \\
\hline & & $254 \mathrm{~nm}$ & $366 \mathrm{~nm}$ \\
\hline Powder as such & Brown & Green & Dark Brown \\
\hline Powder+1N HCl & Light Brown & Green & Light Brown \\
\hline Powder $+50 \% \mathrm{H}_{2} \mathrm{SO}_{4}$ & Black & Black & Indigo \\
\hline Powder $+50 \% \mathrm{HNO}_{3}$ & Yellow & Light green & Black \\
\hline Powder+Glacial acetic acid (GAA) & Brown & Light green & Grey \\
\hline Powder $+1 \mathrm{~N} \mathrm{NaOH}$ in water & Dark Brown & Black & Black \\
\hline Powder $+1 \mathrm{~N} \mathrm{NaOH}$ in methanol & Yellow & Dark Brown & Indigo \\
\hline Powder+Wagner's reagent & Brown & Brown & Indigo \\
\hline Powder+Drangendorff reagent & Yellow & Green & Indigo \\
\hline Powder+Benedict's reagent & Brown & Brown & Indigo \\
\hline Powder+Fehling reagent & Brown & Brown & Indigo \\
\hline Powder+Lead Acetate (1\%) & Brown & Brown & Indigo \\
\hline
\end{tabular}

and storage may spoil the quality of the drug and hence the oil. ${ }^{23}$ Therefore, to assess the quality of $N$. jatamansi it is also necessary to determine volatile oil percentage of the drug. All the values were determined in triplet and the results are depicted in Table 2.

\section{Fluorescence analysis of $N$. jatamansi}

Some constituents in many natural products exhibit fluorescence in the daylight ultra violet light and if the substance itself is not fluorescent, it may often be converted into fluorescent through the application of different reagents. Hence, the qualitative assessment of the test drug is carried out in this manner also which serves as an important parameter for pharmacognostic evaluation of crude drugs. ${ }^{24}$ (Table 3).

\section{Phytochemical analysis of $N$. jatamansi}

The efficacy and pharmacological therapeutic effects of any herbal medicine is depends on their secondary metabolites i.e. phytoconstituents such as alkaloids and glycosides etc. The presence or absence of these phytoconstituents also indicates the quality of the crude drug. ${ }^{24}$ Therefore, it is also necessary to determine the presence of active secondary metabolites in the test drug, the results are shown in Table 4.

\section{TLC of N jatamansi}

TLC is one of the important parameter equips with the qualitative and semi-quantitative information of the drug. If the drug is adulterated or exhausted which in turn may increase or decreases the number of spots 
Table 4: Phytochemical analysis of $N$. jatamansi

\begin{tabular}{|c|c|c|}
\hline Chemical Constituents & Test / Reagents & Inference \\
\hline \multirow[t]{5}{*}{ Alkaloids } & Dragendroff's reagent & Present \\
\hline & Hager's test & Present \\
\hline & Wagner's reagent & Present \\
\hline & Tannic acid test & Present \\
\hline & Mayer's reagent & Present \\
\hline \multirow[t]{4}{*}{ Carbohydrates } & Fehling's test & Present \\
\hline & Molish's test & Present \\
\hline & Barfoed's test & Present \\
\hline & Benedict's test & Present \\
\hline \multirow[t]{3}{*}{ Flavonoids } & Shinoda test & Present \\
\hline & Zinc hydrochloride test & Present \\
\hline & Alkaline reagent test & Present \\
\hline \multirow[t]{3}{*}{ Tannins } & Ferric chloride test & Present \\
\hline & Gelatin test & Present \\
\hline & Lead acetate test & Present \\
\hline \multirow[t]{2}{*}{ Proteins } & Warming test & Present \\
\hline & Biuret test & Present \\
\hline \multirow[t]{4}{*}{ Steroids } & Salkowski test & Present \\
\hline & Sulphur powder test & Present \\
\hline & Hosse's reaction & Present \\
\hline & Moleschott's reaction & Present \\
\hline Glycosides & $\mathrm{NaOH}$ Test & Present \\
\hline Saponins & Frothing with $\mathrm{NaHCO} 3$ & Present \\
\hline Fats and fixed oils & Copper sulphate / Sodium hydroxide & Present \\
\hline
\end{tabular}

\section{Table 5: TLC Profile of $\boldsymbol{N}$. jatamansi}

\begin{tabular}{|c|c|c|c|c|c|c|c|c|}
\hline \multirow{3}{*}{$\begin{array}{c}\text { Drug } \\
\text { Sumbul-ut- } \\
\text { Teeb }\end{array}$} & \multirow{3}{*}{$\frac{\text { Extract }}{\text { Methanolic }}$} & \multirow{3}{*}{$\begin{array}{c}\text { Mobile Phase } \\
\text { Chloroform:Methanol } \\
24: 1\end{array}$} & \multicolumn{6}{|c|}{ Observation } \\
\hline & & & \multicolumn{2}{|c|}{ In long wavelength } & \multicolumn{2}{|c|}{$\begin{array}{c}\text { In short } \\
\text { wavelength }\end{array}$} & \multicolumn{2}{|c|}{$\begin{array}{l}\text { After exposure to iodine } \\
\text { vapours }\end{array}$} \\
\hline & & & $\begin{array}{c}\mathrm{Rf} \\
\text { value }\end{array}$ & $\begin{array}{l}\text { Colour } \\
\text { of Bands }\end{array}$ & $\begin{array}{c}\mathrm{Rf} \\
\text { value }\end{array}$ & $\begin{array}{l}\text { Colour } \\
\text { of Bands }\end{array}$ & $\begin{array}{c}\mathrm{Rf} \\
\text { value }\end{array}$ & $\begin{array}{c}\text { Colour of } \\
\text { Bands }\end{array}$ \\
\hline & & & 0.74 & $\begin{array}{l}\text { Light } \\
\text { blue }\end{array}$ & 0.10 & $\begin{array}{l}\text { Light } \\
\text { Violet }\end{array}$ & 0.03 & Brown \\
\hline & & & 0.81 & $\begin{array}{l}\text { Light } \\
\text { blue }\end{array}$ & 0.18 & $\begin{array}{l}\text { Ash } \\
\text { Colour }\end{array}$ & 0.10 & Light Brown \\
\hline & & & 0.92 & $\begin{array}{l}\text { Light } \\
\text { blue }\end{array}$ & 0.21 & $\begin{array}{l}\text { Ash } \\
\text { Colour }\end{array}$ & 0.34 & Yellowish \\
\hline & & & 0.95 & Pink & 0.46 & $\begin{array}{l}\text { Light } \\
\text { Violet }\end{array}$ & 0.42 & Yellowish \\
\hline & & & & & 0.54 & $\begin{array}{l}\text { Light } \\
\text { Violet }\end{array}$ & 0.50 & Yellowish \\
\hline & & & & & 0.71 & $\begin{array}{l}\text { Ash } \\
\text { Colour }\end{array}$ & 0.71 & Yellowish \\
\hline & & & & & 0.91 & Violet & 0.80 & Yellowish \\
\hline & & & & & 0.95 & $\begin{array}{l}\text { Light } \\
\text { Violet }\end{array}$ & 0.85 & Yellowish \\
\hline & & & & & & & 0.91 & Light Brown \\
\hline & & & & & & & 0.95 & Brown \\
\hline
\end{tabular}


Table 6: HPLC peak table of $N$. Jatamansi

\begin{tabular}{|c|c|c|c|c|c|}
\hline Peak\# & Ret. Time & Area & Height & Area \% & Height $\%$ \\
\hline 1 & 2.800 & 51022490 & 3999862 & 25.974 & 27.040 \\
\hline 2 & 2.958 & 17498737 & 2035176 & 8.908 & 13.758 \\
\hline 3 & 3.112 & 17133712 & 1448847 & 8.722 & 9.795 \\
\hline 4 & 3.358 & 22115659 & 1398390 & 11.258 & 9.453 \\
\hline 5 & 3.631 & 5404008 & 912771 & 2.751 & 6.171 \\
\hline 6 & 3.760 & 12680670 & 967824 & 6.455 & 6.543 \\
\hline 7 & 4.059 & 8507107 & 599396 & 4.331 & 4.052 \\
\hline 8 & 4.399 & 58866076 & 3259988 & 29.967 & 22.038 \\
\hline 9 & 4.714 & 41757 & 9169 & 0.021 & 0.062 \\
\hline 10 & 4.861 & 94619 & 6792 & 0.048 & 0.046 \\
\hline 11 & 6.520 & 42582 & 3473 & 0.022 & 0.023 \\
\hline 12 & 7.137 & 191120 & 21866 & 0.097 & 0.148 \\
\hline 13 & 7.458 & 41893 & 1733 & 0.021 & 0.012 \\
\hline 14 & 7.967 & 4840 & 709 & 0.002 & 0.005 \\
\hline 15 & 8.883 & 3938 & 486 & 0.002 & 0.003 \\
\hline 16 & 9.615 & 6029 & 2355 & 0.003 & 0.016 \\
\hline 17 & 10.715 & 48930 & 3440 & 0.025 & 0.023 \\
\hline 18 & 11.314 & 126621 & 9723 & 0.064 & 0.066 \\
\hline 19 & 11.541 & 93439 & 7904 & 0.048 & 0.053 \\
\hline 20 & 11.843 & 159512 & 11417 & 0.081 & 0.077 \\
\hline 21 & 12.480 & 243216 & 14527 & 0.124 & 0.098 \\
\hline 22 & 13.061 & 98650 & 5827 & 0.050 & 0.039 \\
\hline 23 & 16.800 & 21224 & 1274 & 0.011 & 0.009 \\
\hline 24 & 18.508 & 9267 & 442 & 0.005 & 0.003 \\
\hline 25 & 19.205 & 98329 & 4279 & 0.050 & 0.029 \\
\hline 26 & 20.984 & 13585 & 731 & 0.007 & 0.005 \\
\hline 27 & 21.291 & 21532 & 920 & 0.011 & 0.006 \\
\hline 28 & 21.961 & 16937 & 496 & 0.009 & 0.003 \\
\hline 29 & 23.315 & 25369 & 952 & 0.013 & 0.006 \\
\hline 30 & 23.933 & 247112 & 9334 & 0.126 & 0.063 \\
\hline 31 & 25.328 & 74338 & 2435 & 0.038 & 0.016 \\
\hline 32 & 26.661 & 1442445 & 49067 & 0.734 & 0.332 \\
\hline 33 & 35.632 & 10564 & 249 & 0.005 & 0.002 \\
\hline 34 & 37.411 & 29702 & 523 & 0.015 & 0.004 \\
\hline Total & & 196436011 & 14792377 & 100.000 & 100.000 \\
\hline
\end{tabular}

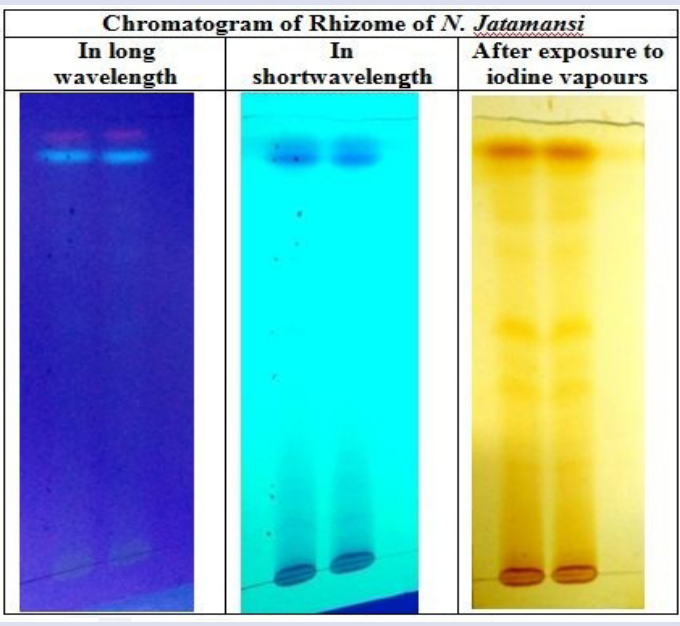

Figure 1: TLC Profile of N. jatamansi rhizome. and change in the Rf values. ${ }^{16}$ The TLC profile alongwith images of TLC are illustrated in Table 5 and Figure 1 respectively.

\section{HPLC profile of methanolic extract of $N$ jatamansi}

The preparative and analytical HPLC has been widely employed for the analysis of herbal medicines in lieu of its high separation capacity. It can also be utilized to analyse almost all constituents of herbal products provided that an optimized procedure is developed which involves optimization of mobile phase and stationary phase along with other chromatographic parameters. ${ }^{25}$ The adulteration and impurities can also be determined by this technique. If there is any change in number of peaks or retention time or area of peaks from standard it indicates adulteration or deterioration in the drug. The HPLC pattern shows 34 peaks and the peak no. 01 and 08 are major peaks having area concentration and retention time as $25.974 \%$ at $2.8 \mathrm{~min}$. and $29.967 \%$ at $4.399 \mathrm{~min}$. respectively followed by peak no. $04,02,03,06$ and 07 with concentration of $11.258 \%, 8.908 \%, 8.722 \%, 6.455 \%$ and $4.331 \%$ respectively. The HPLC profile of the test drug was obtained and recorded for future reference. The details are depicted in Figure 2 and Table 6. 


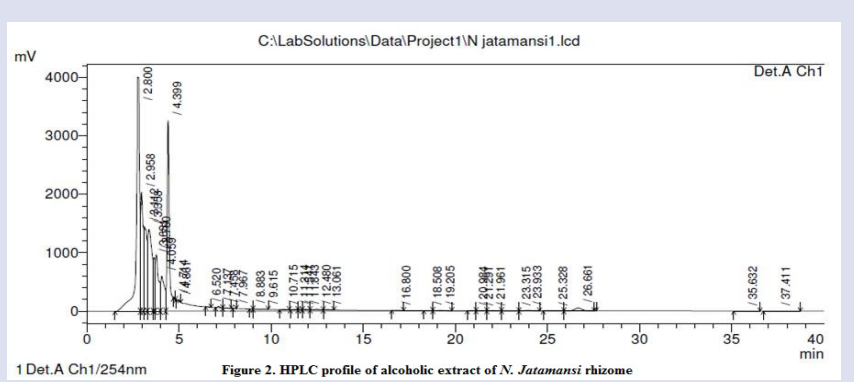

Figure 2: HPLC profile of alcoholic extract of $N$. Jatamansi rhizome.

\section{CONCLUSION}

Present study shows that the methods of standardization and identification of $N$ jatamansi i.e. organoleptic characters along with physicochemical analysis are the basic and useful parameters to analyse the originality of the test drug. A good quality of drug is the assurance of its efficacy. The results of phytochemical analysis and HPLC fingerprinting also play a key role in identification and authentication of $N$ jatamansi. Further these analytical parameters for quality assurance also indicating effectiveness of $N$ jatamansi for treating various body ailments. The data obtained in the present work will be useful in identification, standardisation and quality assurance of different samples of $N$. jatamansi and will also be useful in the preparation of the drug's monograph for inclusion in various pharmacopoeias.

\section{REFERENCES}

1. Pravin $\mathrm{H}$, Nikam, Joseph K, Aruna J, Vilasrao K. Future trends in standardization of herbal drugs. J of App Pharm Sci. 2012;2(6):38-44.

2. Singh V, Dubey $P$, Shrivastava $S$, Rawat AKS. Botanical standardization of the jatamansi, their substitute and adulterant species. IJTK. 2011;10(4):599-03.

3. Madhulika B, Renu MP Ajit KS. In vitro and In vivo biological activities of Nardostachys Jatamansi Roots. Med Aromat Plants. 2013;2(142):2167-0412.

4. Department of Ayurveda, Yoga Naturopathy, Unani, Siddha Homoeopathy (AYUSH). The Unani Pharmacopeia of India. Ministry of Health and Family Welfare (New Delhi), Government of India. 2007;1(1):84-5.

5. Abhay PM, Sarla S, Luigi M, Pryanka T. Formualtion and evaluation of herbal antioxidant face cream of Nardostacys jatamansi collected from Himalaya region. Asian Pac j Trop Biomed. 2014;4(2):679-82.
6. Buechi G, Greuter F, TokoroyamaT. Structure of calarene and stereochemistry of aristolene. Tetrahedron Letters. 1962;3(18):827-33.

7. Shanbhag SN, Mesta OK, Maheswari ML, Paknihar SK, Bhattacharya SC Jatamansin, a new terpenic coumarin from Nardostachys jatamansi. Tetrahedron. 1964;20(11):2605-15.

8. Shanbhag SN, Mesta CK, Maheshwari ML, Bhattacharyya BC. Constituents of Nardostachys jatamansi and Synthesis of Dihydrosamidin and Visnadin from Jatamansin. Tetrahedron. 1965;21:3591-97.

9. Buechi G, Greuter F, TokoroyamaT. Structure of calarene and stereochemistry of aristolene. Tetrahedron Letters. 1962;3(18):827-33.

10. GovindachariTR, Pai BR, Purushothaman, KK, Rajadurai, S. Jatamansone. Tetrahedron Letters. 1959;15:5-9.

11. Sastry SD, Maheswari ML, Chakravarti, KK, Bhattacharyya SC. The Structure of Nardostachone. Tetrahedron. 1967;23(4):2491-93.

12. Rahman A, Tajuddin, Amin KMY. Physicochemical assay alongwith HPLC profile of a pharmacopeial preparation containg Colchicum, Ginger and Aloe. Inernational $\mathrm{J}$ of Pharm Research. 2013;5(4):51-5.

13. Department of Ayurveda, Yoga Naturopathy, Unani, Siddha Homoeopathy (AYUSH). The Ayurvedic Pharmacopoeia of India. Part- I, Vol-II, First Edition, Ministry of Health and Family Welfare (New Delhi), Government of India.190-95.

14. General Medicine Council; British Pharmacopoea, 1968. Pharmaceutical Press, Bloomsbury square, London. 1960;1276-7,1286-8.

15. Rasheed NMA, Negi RK, Juveria M, Siddiqui A, Kazmi MH, Arfin S. et al. Standardization and HPTLC fingerprinting of a Unani compound formulation 'Qurs-eLuboob' with mordern techniques. Hippocratic j of Unani Med. 2016;11(1):87-99.

16. Latif A, Rehman S. Standardization of an herbal medicine- Swertia chirayita linn. Pharmacophore. 2014;5(1):98-108.

17. Dhuna K. Cytoprotective effect of methanolic extract of Nardostachys jatamansi against hydrogen peroxide induced oxidative damage in $\mathrm{C} 6$ glioma cells. ACTA Biochimica Polonica. 2013;60(1):21-31.

18. Kokate CK, Purohit AP, Gohkle SB. Pharmacognosy. 41 ed. Nirali Publication, Pune: A.1-A.6.

19. Rahman A, Tajuddin, Amin KMY. Identification and standardization of pharmacopeal Unani formulation: estimation of marker compounds. Unani Medicus. $2011 ; 1(2): 58-62$

20. Anupam KS, Garima V, Roopak K. Need of standardization of herbal medicines in modern era. Intern J of Phytomedicine. 2016;8(3):300-7.

21. Neeraj C, Bhupinder SS. An overview of advances in the standardization of herbal drugs. J Pharm Educ Res. 2011;2(2):55-70.

22. Zameer M, Rauf A, Qasmi IA. Standardization and safety evaluation of a polyherbal formulation“Kabideen (Syrup). Intern J of Adv Res. 2015;3(9):1105-14.

23. Mohammad R, Shariq S, Roohi Z. Preliminary physico-chemical evaluation of sunun poste mughilan. Hippocratic J of Unani Med. 2014;2:9-19.

24. Sumitra C. Importance of pharmacognostic study of medicinal plants: An overview. J of Pharmacognosy and Phytochemistry. 2014;2(5):69-73.

25. Kirti MK, Leena SP, Vineeta V, Khanvilkar, Vilasrao JK. Fingerprinting techniques in herbal standardization. Indo American J of Pharm Research. 2014;4(2):1049-62.

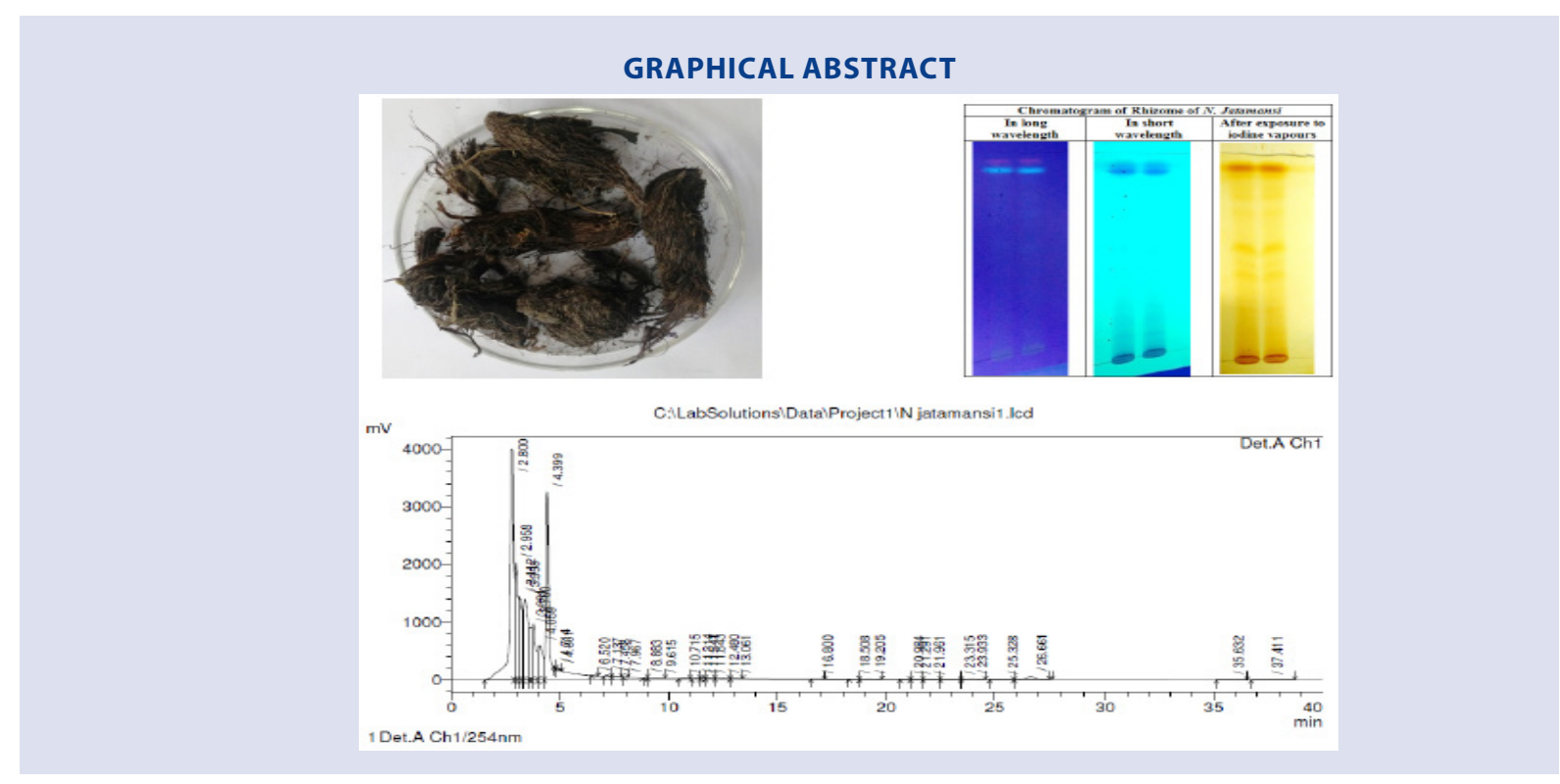




\section{SUMMARY}

- The present study aims towards the evaluation of the parameters involved in the determination of the quality and purity of Nardostachys jatamansi rhizome and its standardization. The parameters used for the standardisation of the test drug includes organoleptic characters, extractive values, ash values, phytochemical analysis, TLC, fluorescence analysis and HPLC profile etc. The study will provide referential information for the good quality, purity and identification for the future batches of Nardostachys jatamansi.

\section{ABOUT AUTHORS}

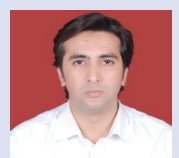

Dr. Aziz ur Rahman is working as Assistant Professor in Department of Saidla (Unani Pharmacy), Faculty of Unani Medicine, Aligarh Muslim University, Aligarh. His research area includes standardization, drug design \& discovery, formulation development and experimental research.

Cite this article: Rashid M, Rahman A, Ahmad OZ, Tajuddin, Mian SS. Physicochemical Analysis of Sumbul-al -Teeb (Nardostachys jatamansi D.C.) Rhizome along with its HPLC Profile. Pharmacog J. 2018;10(2):278-84. 